\title{
Ecosystem Services in Differently Used Agroecosystems along a Climatic Gradient in Slovakia
}

\section{Jarmila Makovníková1, Boris Pálka ${ }^{1}$, Miloš Širáňn ${ }^{1}$, Beáta Houšková1, Radoslava Kanianska², Miriam Kizeková ${ }^{3}$}

\author{
${ }^{1}$ National Agricultural and Food Centre, Soil Science and Conservation Research Institute, Bratislava, Slovenská \\ ${ }^{2}$ Department of Environment, Faculty of Natural Sciences, Matej Bel University, Banská Bystrica, Slovenská \\ ${ }^{3}$ National Agricultural and Food Centre, Grassland and Mountain Agriculture Research Institute, Banská Bystrica, Slovenská \\ Email: j.makovnikova@vupop.sk
}

How to cite this paper: Makovníková, J., Pálka, B., Širáň, M., Houšková, B., Kanianska, R. and Kizeková, M. (2018) Ecosystem Services in Differently Used Agroecosystems along a Climatic Gradient in Slovakia. Open Journal of Ecology, 8, 623-645.

https://doi.org/10.4236/oje.2018.812037

Received: March 20, 2018

Accepted: December 14, 2018

Published: December 17, 2018

Copyright $\odot 2018$ by authors and Scientific Research Publishing Inc. This work is licensed under the Creative Commons Attribution International License (CC BY 4.0).

http://creativecommons.org/licenses/by/4.0/

(c) (i) Open Access

\begin{abstract}
For analysis and evaluation of potential of agroecosystem (arable land and grassland) services (provisioning, regulating and cultural) in Slovakia we have created a mapping unit combining these input layers: slope topography, soil texture and landuse in four climatic regions. Evaluated potential of agroecosystem services was categorised into five categories (very low, low, medium, high and very high). Our results show that climate has the most significant impact on agroecosystem services. Warm, dry lowland region has a higher potential of provisioning services, regulation of water regime, filtration of pollutants and control of soil erosion in comparison to moderately warm and cold regions. In moderate cold region, more than $90 \%$ of the total area of arable land has low potential of water regime regulation and cleaning potential (immobilization of risk elements). In the moderate warm climatic region, there is a high share of categories of low and moderate potential of provisioning services and low and moderate potential of water regime regulation. Majority of the total area of warm climatic region belongs to the categories of moderate to high potential of provisioning services and high potential of regulation of water regime. In this climatic zone low potential categories of risk elements immobilization are present in more than $65 \%$ of the arable land total area. On the other hand, in very warm climatic zone, more than $89 \%$ of the total area of arable land belongs to the category with a very high cleaning (buffering) potential. Potential of natural conditions for recreation is higher only in moderate cold and moderate warm climatic zones with a higher proportion of area of grassland agroecosystems and protected areas NATURA 2000. Moreover, the methodology developed in this paper is
\end{abstract}


replicable and could be applied by planners in the case that they are proficient in geographical information systems.

\section{Keywords}

Agroecosystem Services, Climatic Zone, Mapping, Trade-Offs, Synergies

\section{Introduction}

Ecosystem services are inherently defined mutual interaction between ecological and social systems because only those ecosystem processes that contribute to the fulfillment of human needs, are defined as ecosystem services [1] [2] [3] [4]. The ecosystem services approach offers the ability to explore the influence of land use and practices on natural capital stocks, on the processes that build and degrade these stocks, and on the flow of ecosystems services from the use of these stocks [5]. Service-providing ecosystems are denoted as natural capital [6] [7]. Ecosystem services linked to natural capital can be divided into three main categories (provisioning, regulating and cultural) [2] [5]. Agroecosystem services are the multiple goods and services provided to humanity by nature in combination with additional anthropogenic inputs in agricultural systems [2]. Concept of agroecosystem service combines environmental and socio-economic approach to the analysis and evaluation of natural capital. For practical use as well as legislative use of the concept of agroecosystem services in planning and prospective studies, qualitative and quantitative analysis and evaluation of agroecosystem linked to spatial visualization at the required level are essential [7]. The concept of agroecosystem services receives increasing attention in recent years with an emphasis on national assessment. Following this trend, an integrated evaluation and mapping of agroecosystem services was carried out in the Slovak Republic [8].

Agricultural systems are intensely managed by humans and are more controlled and regulated than majority of the other ecosystems [5]. Traditionally, agroecosystems have been considered primarily as sources of provisioning services, but more recently their contributions to the other types of ecosystem services have been recognized [2] [9], such as regulating and cultural services [5] [10] [11]. Recent conceptual works used the ecosystem services approach to highlight the importance of pedosphere to the human well being and prosperity [12] [13]. We consider the agroecosystem not only as means of production but also as a part of the natural environment, where the pedosphere has functions other than food production [14] [15]. The agroecosystem based on soil is multifunctional in all conditions, both in terms of its processes and functions and services [16]. The cascade model developed by Haines-Young and Potschin [17] demonstrated how soil functions can contribute to ecosystem services. According to Greiner et al. [18] soil and their functions are critical to ensure the 
provision of ecosystem services. Nevertheless, agroecosystem services at the national level, were not assessed on the context of the Slovak Republic. In Slovakia, Juráni [19], Bujnovský et al. [20], Makovníková, Barančíková and Pálka [21] and Barančíková et al. [22] have been also dealing with assessment of soil functions that are the basis for the evaluation of agroecosystem services. These authors define a minimum collection of soil indicators for sufficient assessment of soil functions. These indicators form our basis for agroecosystem services evaluation.

While the concept of natural capital and economic services are widely accepted and their potential contribution to better environmental management is also acknowledged [9] [23] [24], their practical applications such as distribution and mapping are still insufficient and limited. The models and their map presentations should reflect biophysical factors on one hand, but on the other hand they should be applicable within administrative units for better application of models in decision-making [25]. Ecosystem services and natural capital are inherently spatial by nature although some services are easier to map then others. According to Costanza et al. [26], landscape metrics quantifies physical landscape structures which themselves determine processes and functions. Landscape metrics has therefore to be considered as meaningful parameters together with the others in ES mapping and evaluation [27]. Ecosystem services evaluation and mapping are useful for assessment of landscape capacities and potentials to supply ecosystem services [10] and to adapt the management to local conditions [18] [28]. These maps are also important to assess spatial trade-offs among ES and synergies among multiple ES [27]. Because the provision of ecosystem services depends on biophysical conditions and changes over space and time due to human induced land cover, land use and climatic changes [10] [29], the supply and demand of services may differ geographically [30]. A number of recent studies have evaluated and mapped the supply of services at global [31], continental [32], national [3] [33] [34] [35] or regional scales. For this reason, it is necessary to understand better where and what services are provided by a local area of land or region [30]. The most common indicators for mapping ecosystem services are land cover, soils, vegetation and nutrient related indicators. According to a review of different approaches used to model ecosystem services, regulating services were the most commonly modeled, followed by provisioning and cultural services and supporting processes [36]. Provisioning services strongly depend on the extent of managed land and the land use intensity. However, for quantification of productivity or food provision, further information, for example on soil quality or soil management, location or climatic zone, is essential to derive a valid estimation on food provision [4]. Cultural ecosystem services are less in the foreground to be put on maps, because researchers must rely on proxies for their quantification [37]. Ecosystem services models can vary from simple expert based scoring systems to complex ecological models cycles of carbon, nitrogen and water [27]. Linking ecosystem services models to landscape coverage is one 
of the conditions for using these models to monitor changes in land use management, spatial planning, and implementation of the assessment of the potential of natural capital services in socio-economic planning within the region and landscape [17]. Burghard and Maes [27] highlights the importance of the process of mapping ecosystem services that can be used to visualise impacts which are often considered invisible externalities of agriculture, both positive and negative.

The aim of this study was to assess and map agroecosystem services on national level and to evaluate agroecosystem services along the climatic gradient in Slovak Republic. The paper aims to describe the use of GIS techniques in creating a uniform spatial unit for agroecosystem services inventory and compare the spatial configuration, synergies and trade-offs of agroecosystem services along the climatic regions.

\section{Material and Methods}

\subsection{Study Area}

Slovakia is a land-locked country in Central Europe between latitudes $47^{\circ}-49^{\circ} \mathrm{N}$ and longitudes $15^{\circ}-21^{\circ} \mathrm{E}$. The average rainfall in lowlands is about 600 millimeters per year, in midlands about 700 millimeters per year and the biggest average rainfall rate belongs to mountain areas-approximately 1500 millimeters per year. The daily average temperatures in winter are around freezing $\left(0^{\circ} \mathrm{C}\right.$ or $\left.32^{\circ} \mathrm{F}\right)$, while in summer they are around $13 / 15^{\circ} \mathrm{C}\left(55 / 59^{\circ} \mathrm{F}\right)$ at night, and $25 / 27^{\circ} \mathrm{C}\left(77 / 81^{\circ} \mathrm{F}\right)$ during the day. Its terrain is mostly hilly, upland and mountainous in the central, north and north-eastern parts of the country where the permanent grasslands mainly occur [38]. For this study, we used a classification of agro-climatic regions provided by the Information Service of the National Agricultural and Food Centre-Soil Science and Conservation Research Institute [39]. In this classification, 11 agro-climatic regions were identified according to long-term average temperatures in January, average growing-season temperatures, daily average temperatures sums $\left(\mathrm{T}>10^{\circ} \mathrm{C}\right)$, the length of period with daily temperatures $\mathrm{td}>5^{\circ} \mathrm{C}$ and the climatic moisture indicator according Budyko calculated by Tomlain [40]. For our purpose, the original vector layer with 11 categories were merged into 4 categories (climatic regions: very warm (VW), warm (W), moderate warm (MW) and moderate cool climatic region (MC)) and transfered to a raster with a resolution of $100 \mathrm{~m}$ (Figure 1).

Agroecosystems, which occupy $49.3 \%$ of the Slovak republic, were assessed. To estimate the surplus area of agroecosystems (arable land and permanent grasslands) in each of the climatic regions (Table 1) we used data provided by Land Parcel Identification System (LPIS).

The structure of the assessment is given by one ecosystem type-agricultural ecosystem and 6 ecosystem services delivered from this ecosystem (provisioning services, regulating services-regulation of water regime, regulation of water 
erosion, cleaning potencial of ecosystem, regulation of climate and cultural services-potencial of outdoor recreation). Ecosystem types are further classified into two ecosystem categories based on the management, arable land and permanent grassland.

\subsection{Data}

To the primary geo-referenced data belongs the Digital database of soil profiles of Geochemical atlas of Slovakia (GchA-2965 localities on agricultural soil). Geochemical atlas database contains data of agrochemical soil properties and risk elements concentration determined from the samples collected during the national project "Geochemical atlas of soils of Slovakia" [41]. Further, there are geo-referenced data, as a source of additional information (data of relevant soil properties) on the primary geo-referenced data. As secondary geo-referenced data was used Digital database of Soil monitoring of Slovakia (CMSP) represented by digital data archive of the "Partial monitoring system-Soil" as a part of the Complex Environment Monitoring of Slovakia [42]. Soil indicators are included in the soil monitoring system in Slovakia according to the recommendation of the European Commission for united soil monitoring system in Europe [43]. All monitored indicators are quantifiable.

Table 1. Surface areas: arable land and grassland in climatic regions (ha).

\begin{tabular}{ccccc}
\hline Climatic region & $\begin{array}{c}\text { Moderate cool } \\
(\mathrm{MC} 4)\end{array}$ & $\begin{array}{c}\text { Moderate warm } \\
(\mathrm{MW})\end{array}$ & $\begin{array}{c}\text { Warm } \\
(\mathrm{W} 2)\end{array}$ & $\begin{array}{c}\text { Very warm } \\
\text { (VW1) }\end{array}$ \\
\hline Arable land & 68,436 & 183,632 & 299,712 & 765,804 \\
Grassland & 168,790 & 173,456 & 60,363 & 40,231 \\
\hline
\end{tabular}

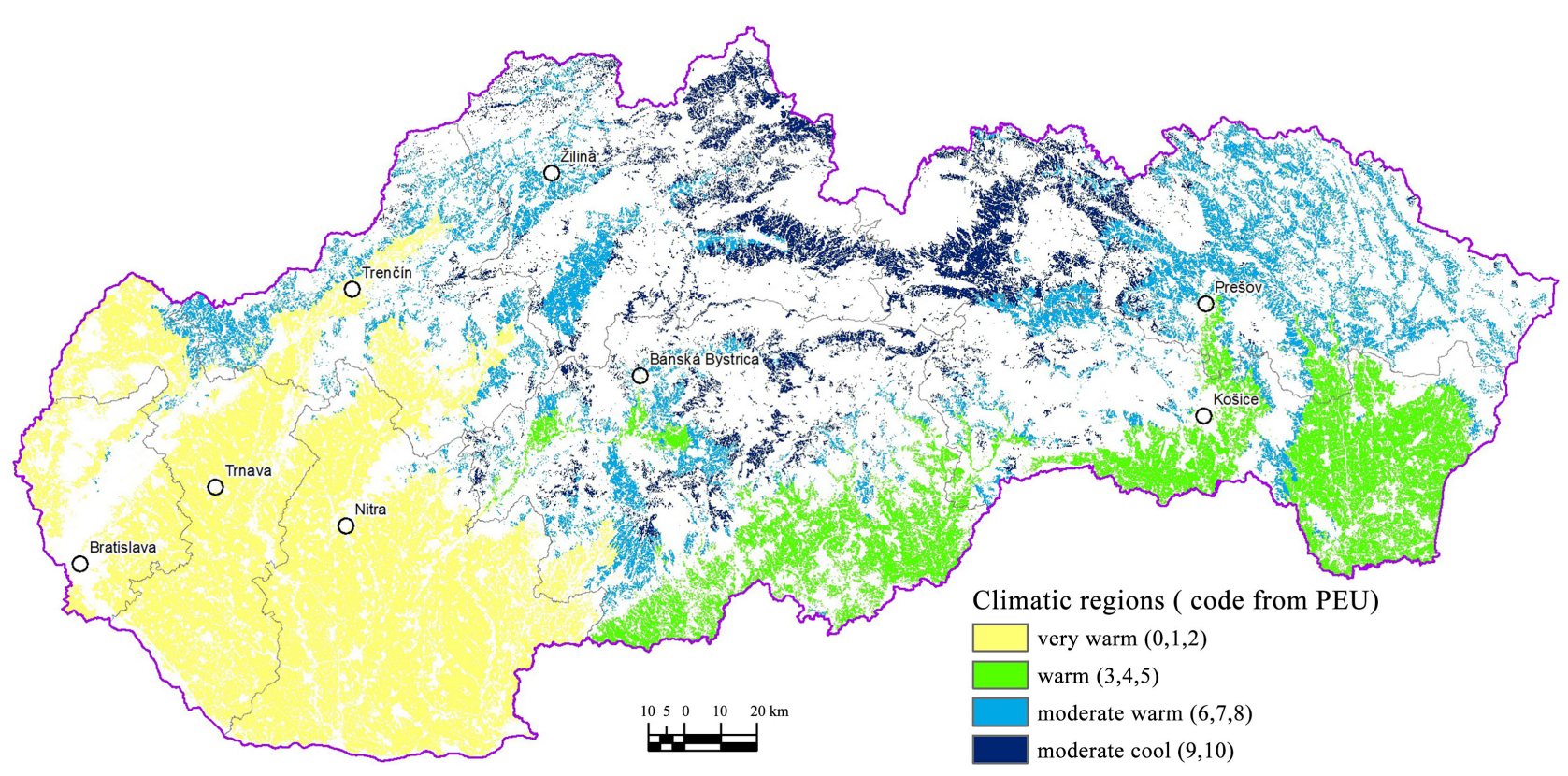

Figure 1. Categories of climatic regions in the Slovak Republic. 


\subsection{Methods of Assesssment and Mapping the Potential of Agroecosystem Service}

Ecosystem services potential (capacity) has been characterized by Burghard et al. [2] as the hypothetical maximum yield of selected ecosystem services. Integrated approach towards the assessment of ecosystem services with the application of expert methods enables to link data on soil parameters, morphological and biophysical parameters of soil with the data on soil exploitation into one concept, i.e. the concept of agroecosystem services. Biophysical spatial quantified data is used by many authors to evaluate ecosystem services in their work [1] [44] [45]. For analysis and evaluation of potential of agroecosystem services we have created a mapping unit combining these input layers: slope topography, soil texture and usage of land in four climatic regions. The resulting layer is elaborated at the national level for the whole territory of the Slovak Republic using the methods and tools offered by geographic information systems (GIS). We used ESRI's software package ArcGIS for Desktop Advanced version 10.3. Mapping units are also compatible with the spatial units in international database (Corine Land Cover) which carries information on the use of land. Within each unit, we calculated a weighted average of the potential of each agroecosystem service for the territory of the Slovak Republic, which is characteristic for the spatial aggregate of functional unit. Forouzangohar et al. [12] concluded that the best sampling and mapping strategy would be a regular grid scheme.

Moreover, the assessment and mapping methodology developed in this paper is replicable and could be applied by planners in case they are proficient in geographical information systems at different levels, from regional (district) to national level.

\subsection{The Provisioning Services}

The basis for analysing the potential for the provisioning agroecosystem services was a point value within a range of 0 - 100 that indicate a productive potential based on typological and production classification of agricultural soils of Slovakia [15] [46]. Point value is the sum of points assigned to the average yield of crop production according to the soil type ( 0 - 60 points), slope and its aspect ( 0 - 15 points), stone content and soil depth (0 - 15 points) and soil texture (0 - 10 points). Values were categorised into five groups (range of 20 points) and the categories of provisioning service potencial are as follows: 1 ) very low potential (lower than 20 points), 2) low potential (20 - 40 points), 3) medium potential (41 - 60 points), 4) high potential (61 - 80 points), 5) very high potential (more than 80 points).

\subsection{The Regulating Services}

Potential of regulation of water regime (soil water storage) was obtained from maps and databases [47] (Bujnovský et al., 2009). Its values are given in mm and are determined on the basis of the value of retention water capacity recalculated 
to soil water storage in context with the soil depth. Values were categorised into five groups and the categories are as follows: 1) very low potential (<135 mm), 2) low potential (135 - $175 \mathrm{~mm}), 3)$ medium potential (175 - $215 \mathrm{~mm})$, 4) high potential (216 - $275 \mathrm{~mm}), 5)$ very high potential $(>275 \mathrm{~mm})$.

\subsection{Potential of Regulation of Soil Erosion, Regulation of Water Erosion}

Regulation of water erosion was derived from maps and databases based on empirical model of the universal soil loss equation-USLE [48] (Wischmeier and Smith, 1978), Styk and Pálka, 2005). The relative ratio of the calculated values of soil loss and acceptable erosion expresses the degree of soil erosion endangerment (SEOP value, [49]). Values were categorised into five categories: 1 ) very low potential (more than 2.60), 2) low potential (2.21 - 2.60), 3) medium potential (1.81 - 2.20), 4) high potential $(1.40-1.80), 5)$ very high potential (less then 1.40$)$.

\subsection{Cleaning Potential of Agricultural Land Ecosystem}

Cleaning potential of ecosystem of agricultural land depends on the actual soil contamination and potential of soil sorbents and was calculated as accumulative function:

Cleaning potential $=$ Sorption potential of soil + Potential of total content of inorganic contaminants evaluated according to The Slovak Law 220/2004 Coll. (the method is mentioned detaily in our previous article [21]. Point evaluation of Sorption potential of soil was calculated as a sum of quality factors ( $\mathrm{pH}(0-4$ points), $Q_{6}^{4}(0-1$ points $)$ and quantity factors (Cox (0 - 1 points), H-depth of humus horizon (0 - 2 points) ) according to the function: $P S=F(p H)+F(Q 46)+$ $\mathrm{F}(\mathrm{Cox}) \times \mathrm{F}(\mathrm{H})$. The overall rating is determined as a sum of the soil contamination and Sorption potential of soil. The high soil contamination was evaluated by the high point value and present high risk (0 - 5 points). On the other hand, high soil Sorption potential results in low point value and decreases possible transport risk of harmful elements in soil. Sum of values were categorised into five groups and respective categories are as follows: 1) very low potential (more than 6.50 points), 2) low potential (5.51 - 6.50), 3) medium potential (4.51 - 5.50 points), 4) high potential (3.50 - 4.50 points), 5) very high potential (lower than 3.50 points).

\subsection{Climate Regulation}

In agroecosystems of agricultural land, soil organic matter represents the largest share of total organic carbon found in the soil. Agroecosystems contribute to climate regulation by sequestration of organic carbon in the soil. Soil organic carbon stock (SOCS) was calculated as a function:

Soil organic carbon stock (depth $0-30 \mathrm{~cm})$ in $\mathrm{t} \cdot \mathrm{ha}^{-1}=10 \times(\mathrm{BD}(0-10 \mathrm{~cm}) \times$ $\operatorname{SOC}(0-10 \mathrm{~cm})+\mathrm{BD}(10-20 \mathrm{~cm}) \times \operatorname{SOC}(10-20 \mathrm{~cm})+\mathrm{BD}(20-30 \mathrm{~cm}) \times$ SOC $(20-30 \mathrm{~cm})), \mathrm{BD}$-soil bulk density in $\mathrm{g} \cdot \mathrm{cm}^{-3}$, SOC—soil organic matter 
content in \% [50]. The categories are as follows: 1) very low potential (lower than 58.00 $\left.\mathrm{t} \mathrm{C} \mathrm{ha}^{-1}\right)$, 2) low potential (58.00) $\left.62.00 \mathrm{t} \mathrm{C} \mathrm{ha}^{-1}, 3\right)$ medium potential $\left(62.01-67.00 \mathrm{t} \mathrm{C} \mathrm{ha}^{-1}\right)$, 4) high potential (67.01 - $\left.72.00 \mathrm{t} \mathrm{SOC} \mathrm{ha}^{-1}\right)$ 5) very high potential (more than $72.00 \mathrm{t} \mathrm{SOC} \mathrm{ha}^{-1}$ ).

\subsection{Cultural Ecosystem Services}

All agro-ecosystems are considered to be potential providers of such services. Agroecosystems also have the potential for providing cultural ecosystem services, particularly recreational activities linked to natural resources, such as hiking, biking, cross-country skiing. Recreation potential was evaluated through agroecosystem landscape components that have a specific link with summer, winter and year-round recreation. The capacity of ecosystems to provide recreational services depends on particular uniqueness of the site, its accessibility and the surrounding infrastructure. Point value is the sum of points assigned to the altitude ( 1 - 3 points), inclination ( 1 - 3 points), drainage and precipitation and temperature ( 1 - 4 points) and distance to the roads ( 1 - 4 points). The recreational potential for all these activities was calculated as the sum of potentials for individual recreational activities without added points (Natura 2000). These were added only to the final sum in order to prevent multiple evaluations of additional factors. This method is described in detail in our previous article [29], where we compared the use of this model and SolVES model (according to Sherrouse et al., [51]) in the case study. The categories of agroecosystem to provide outdoor recreational activity are as follows: 1) very low potential (lower than 6.00 points), 2) low potential (6.01 - 9.00 points), 3) medium potential (9.01 - 12.00 points), 4) high potential (12.01 - 15.00 points), 5) very high potential (more than 15.00 points) and:low relevant capacity (from 2.01 to 3.09 points), medium relevant capacity (from 3.10 to 5.09 points), high relevant capacity (from 5.10 to 7.09 points), very high relevant capacity (higher than 7.10 points).

\section{Results and Discussion}

Evaluation of agroecosystem services linked to spatial visualization allows to optimize the management of agroecosystems, thereby to promote synergies between ecosystem functioning and the social dynamics of respective region. Explicit modelling of agroecosystem services is considered to be one of the main requirements for implementation of the concept of these services in institutional decision-making. Krkoška, Lorenzová et al. [52] and Kanianska et al. [53] identified land use and land cover as a major driving force leading to the differencies in agroecosystem services potential. Another important driving force affecting the distribution of agroecosystem services is climatic region [54], that impacts distribution of these services as well as interaction between them [55] [56] [57]. The correlations between climatic region categories and agroecosystem services for arable land and grassland in the Slovak Republic shows in Table 2. 
Table 2. Correlation between clima categories and agroecosystem services for arable land and grassland.

\begin{tabular}{ccccccc}
\hline & \multicolumn{5}{c}{ Agroecosystem services } \\
\cline { 2 - 6 } $\begin{array}{c}\text { Correlation } \\
\text { coefficients }\end{array}$ & Provisioning & \multicolumn{5}{c}{ Regulating services } \\
\cline { 3 - 6 } & & water & erosion & cleaning & clima & \\
\hline Arable land & $-0.77^{\star * *}$ & $-0.59^{* * *}$ & $-0.38^{* *}$ & $-0.78^{* * *}$ & $0.74^{* * *}$ & $0.34^{*}$ \\
Grassland & $-0.64^{* * *}$ & $-0.53^{* * *}$ & $-0.36^{*}$ & $-0.66^{* * *}$ & $0.14 \mathrm{~ns}$ & $0.46^{* * *}$ \\
\hline
\end{tabular}

Significance labels: ${ }^{* * *} \mathrm{p}<0.001,{ }^{* *} \mathrm{p}<0.01,{ }^{*} \mathrm{p}<0.05$, ns: non significant.

Positive correlation coefficient indicates the positive effect of cold climate zone, while negative coefficient indicates the positive influence of warm climate zone. The warm and dry lowland region has higher production potential, water regime regulation, pollutant filtration, and soil drainage in comparison to slightly warm to cool regions. These results are consistent with the place of occurence of soil, its properties, processes and functions in the concept of agroecosystem services [8] [20] [53].

The potential of the provisioning service of agricultural land is determined by its location in the landscape with the climatic conditions (temperature and precipitation) and it is a combination of abiotic, biotic, morphological and socio-economic factors (Figure 2). In Slovakia 29.14\% of ecosystems of agricultural land has very high potential for provisioning services. They are mainly ecosystems of arable land, located in warm climate in the Danube basin. The high level of provisioning services (crop poroduction) indicates Spake et al. [58] in his work for widest lowland valleys in North Alps, where agricultural areas are overrepresented. The main limiting features of low potential of provisioning services are relatively cool climate and considerable sloppiness, limited depth or relatively high stoniness of soils in such ecosystem. In this category the predominant ecosystems are permanent grasslands. Our results show that the proportion of the category with higher potential of the provisioning service increases from the cool climate to very warm (Figure 2) (for arable land from cool climate with prevailing low potential to very warm with very high potential, for grassland from cool climate with lowpotential to very warm with high potential of provisioning services).

In Slovakia $27.47 \%$ of the area of agricultural ecosystems has very high potential for regulation of water regime (accumulation of water in the soil) (Figure 3).

They are mostly ecosystems of arable land located in Eastern Slovak Lowland, Danubian Upland, South-Slovak Basin and Košice Basin with heavy clay loam and clayey deep soils without skeleton. In Slovakia out of the total area of agricultural land the highest proportion (35.96\%) have ecosystems with high potential for regulation of water regime (Figure 3). Ecosystems with low potential for water storage occupy $21.21 \%$ and they are located on deep to moderately deep, light soils without skeleton and on moderately heavy, slightly 


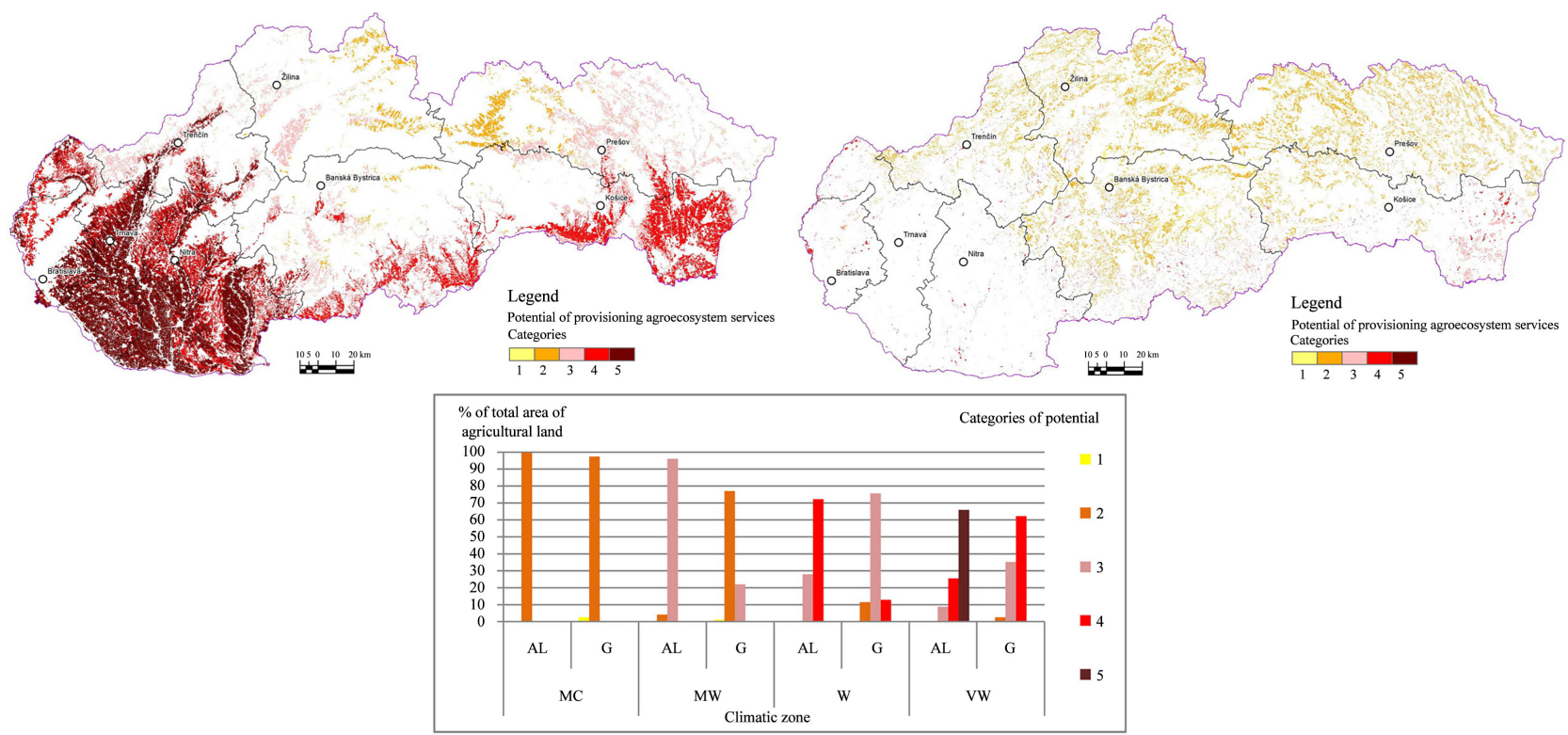

Figure 2. The potential of the provisioning service of agricultural land (arable land-AL-Figure to the left, grassland-G-Figure to the right), percentage of the area of each category of potencial in four climatic regions. Explanations: the categoriesof potential: 1) very low potential, 2) low potential, 3) medium potential, 4) high potential, 5) very high potential.

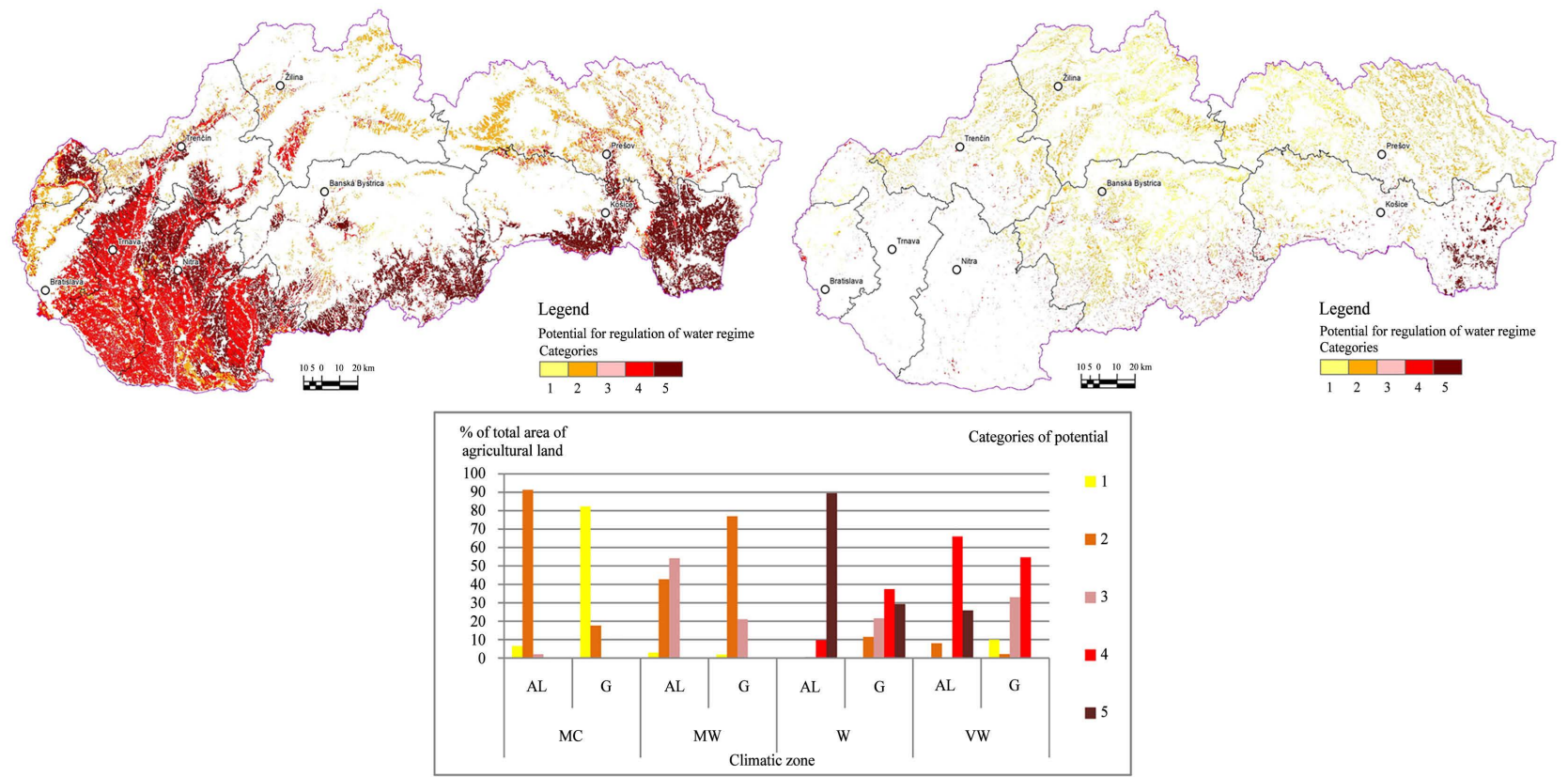

Figure 3. The potential of regulation of water regime of agricultural land (arable land-AL-Figure to the left, grassland-G-Figure to the right), percentage of the area of each category of potencial in four climatic regions. Explanations: the categoriesof potential: 1) very low potential, 2) low potential, 3) medium potential, 4) high potential, 5) very high potential.

to moderately skeletal soils. The greatest influence on water storage potential in both ecosystems has climate, but the impact of soil texture is also significant. Potential of water regime regulation within both types of ecosystems increaces from the cooler to the warmer climate and the highest potential is most represented in areals with warm climate, where deep clay soils developed on clay 
sediments of former seas and lakes, as well as rivers (alluvial cones, aggradational levee) occur and are situated in the foothill parts of lowlands and in the basins [59].

Agroecosystems of arable soils have a high to very high potential for regulation of soil erosion, regulation of water erosion (92\% out of the total area of arable land). Arable land is located mainly in flat areas where low risk of water erosion occurs (Figure 4). These values of soil erosion significantly correlate with the attribute of slope $(r=-0.72, p=0.0008)$. Another prerequisite for higher potential for regulation of water erosion on arable land is presence of deep soils, and consequently higher limit for acceptable soil loss. When considering the overall coverage of land by permanent grassland (land registered in LPIS as permanent grasslands), the potential for soil erosion control achieves very high levels (total area of permanent grasslands- $100 \%$, is classified to the category with the very high potential) [8]. The potential to regulate soiltransport is increasing with warmer climate in case of arable land as well as permanent grassland. This is related to the occurrence of deep soils in lowland areas, where warm and very warm climatic regions predominate, and the limit for acceptable loss of soil is higher. In case of arable soils, there is a potential for regulation of soil erosion at approximately the same level in moderate cool (MC) and moderate warm (MW) climatic zone (Figure 4). In general, grassland potential to regulate soiltransport rises from the $\mathrm{MC}$ climatic zone to the VW climatic zone. The grassland potential is over $80 \%$ in the VW climatic zone (Figure 4).

Cleaning potential of ecosystems in agricultural land depends on the potential for contamination and potential of soil sorbents with high affinity to inorganic pollutants. Out of the total agriculrural land in Slovakia, $41.67 \%$ of ecosystems have very high potential for soil cleaning (immobilization of inorganic pollutants). They are mainly ecosystems of arable land with high carbonate content developed on loess, located in the Danube and the Eastern Slovak Lowlands without any anthropogenic and geochemical depositions (Figure 5). This is based on agrosystems with optimal soil parameters in relation to the ecosystem filtration service [21] [60] [61] [62]. Ecosystems of arable land of low potential $(41.12 \%$ of the area) are developed on fluvisols (along Váh River, Hron River and Bodrog River). Low cleaning potential of these ecosystems is due to a higher number of risk elements in alluvial sediments, anthropogenic deposition and low potential of soil sorbents (low $\mathrm{pH}$, low content of carbonates, and low content of organic matter of lower quality). However, grassland ecosystems are also strongly involved in low category of cleaning potential. Permanent grasslands mostly use farmland ecosystems located at higher altitudes as well as steeper slopes, on soils with lower sorption potential, and on soils developed on substrates with higher content of risk elements. Areas occuring in moderately cold to moderately warm climatic regions, with steeper slopes, and a higher percentage of clay particles have very low and low potentials. Very warm climatic region, mild slope and medium content of clay fraction prevail in areas with high and very high filtration potential. 


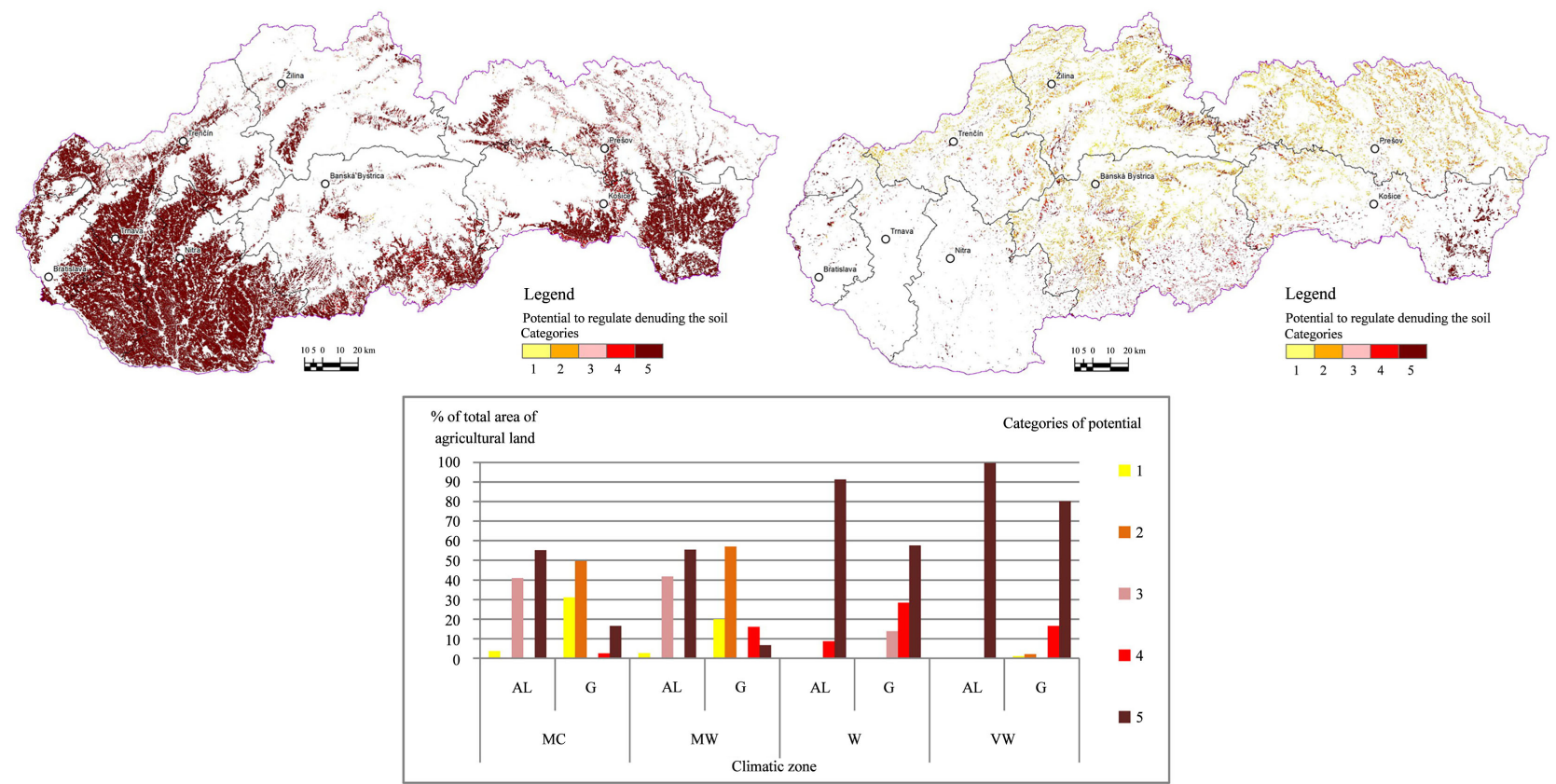

Figure 4. The potential of soil erosion in agricultural land regulation (arable land-AL_Figure to the left, grassland-G-Figure to the right), percentage of of each category area for potencial in four climatic regions. Explanations: the categoriesof potential: 1) very low potential, 2) low potential, 3) medium potential, 4) high potential, 5) very high potential.

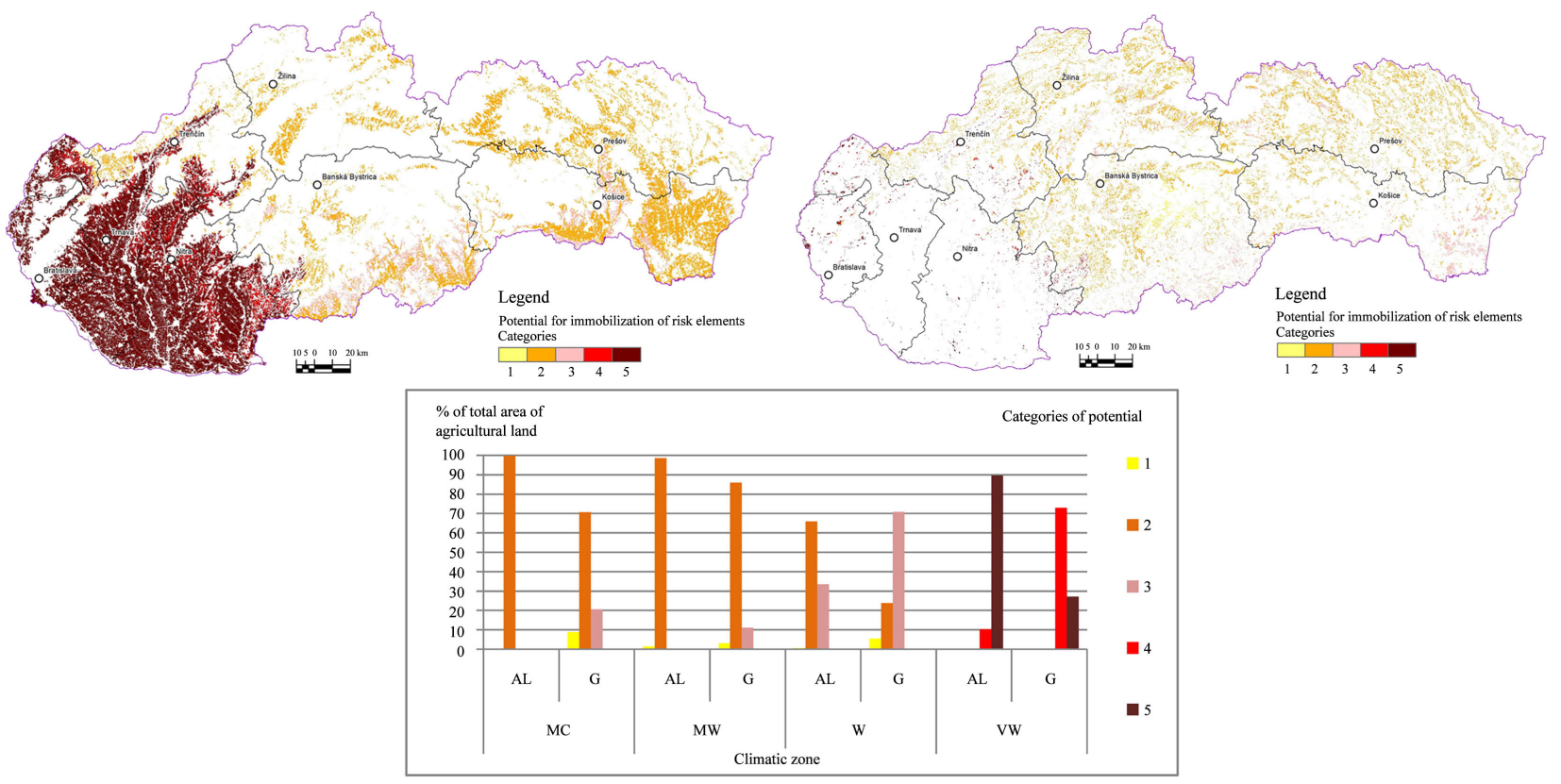

Figure 5. The cleaning potential of agricultural land (arable land-AL_Figure to the left, grassland-G-Figure to the right), percentage of the area of each category of potencial in four climatic regions. Explanations: the categoriesof potential: 1) very low potential, 2) low potential, 3) medium potential, 4) high potential, 5) very high potential.

Carbon stored in ecosystems is an important indicator of regulation services potential [34] whose amount depends on land use and land management practices [52]. In agroecosystems of agricultural land, soil organic matter represents the largest share of the total soil organic carbon stock. Agroecosystems 
contribute to climate regulation by organic carbon sequestration in soil. Soil organic carbon content can be used to represent the carbon sequestration and can be used as an indicator in climate regulation potential service [12]. The results of percentage distribution of various categories of potential of climate regulations are significantly influenced by the ecosystems of arable land due to high share of area of these ecosystems in the total area of agricultural land. Out of the total area of agroecosystems for agricultural land up to $94.83 \%$ belong to the category of low potential of climate regulations (Figure 6). Agroecosystems of arable land located in lowlands are characterized by low potential for climate regulation and low average stocks of soil organic carbon. In higher altitudes, the average organic carbon stocks, and thus the potential of climate regulation is slightly rising.

The low potential of climate control for agroecosystems of arable soils is mentioned in Burghard et al. [63] work. The average stock of soil organic matter in arable land of Slovakia (at a depth $0-30 \mathrm{~cm}$ ) ranges from $59 \mathrm{t} \mathrm{C} \mathrm{ha}^{-1}$ (soils in altitudes from 0 to $300 \mathrm{~m}$ a.s.l.) to $67 \mathrm{t} \mathrm{C} \mathrm{ha}^{-1}$ [64]. Carbon sequestration in arable soils is lower compared to the grassland [50] within the same soil type, therefore, in case of agroecosystems of arable soils there are no categories of high and very high potential of climate control. Cambel and Souster [65] and Schnitzer [66] report that intensive soil management reduces the amount of organic matter in the soil [66]. The average stock of soil organic matter in ecosystems of slovakian grasslands $\left(0-30 \mathrm{~cm}\right.$ deep) is ranging from $73 \mathrm{t} \mathrm{C} \mathrm{ha}^{-1}$ (soil at altitudes from 0 to $300 \mathrm{~m} \mathrm{~nm}$ ) to $86 \mathrm{t} \mathrm{C} \mathrm{ha}^{-1}$ (land at an altitude above $600 \mathrm{~m}$ a. s. 1.) [64]. The high and very high category of climate regulation is up to $58.04 \%$ of the agricultural grasslands area. In case of grassland ecosystems, cambisols, which are the most widespread soil's type in Slovakia [67], are dominant soil type at higher altitudes $(>300 \mathrm{~m} \mathrm{~nm})$. Higher representation of the high category of climate control was also established in warm climatic zone (Figure 6). At elevated average temperatures, soil organic matter stock in arable soils decreased, as organic carbon inputs of plant residues and manure are not able to eliminate carbon losses due to faster mineralization [50] [68]. Agroecosystems of arable soils in colder regions have a higher potential for climate control.

Agroecosystems also have the potential for providing cultural ecosystem services, particularly recreational activities linked to natural resources, such as hiking, biking, cross-country skiing. The capacity of ecosystems to provide recreational services depends on particular uniqueness of the site, its accessibility and the surrounding infrastructure. Agroecosystems of arable land are predominantly of very low to low potential of natural conditions for recreation. In Slovakia $53.82 \%$ of permanent grassland area has high and very high natural conditions potential for outdoor recreation. On the contrary to ecosystems of arable land, grassland agroecosystems are located close to the protected Natura 2000 sites in areas with steeper sloppiness and at higher altitude. Agroecosystems have predominantly very low to low potential of natural preconditions for recreation 
(Figure 7). The perception of the landscape in intensively and extensively farmed areas is also different, which, according to Martens [69], may negatively affect the attractiveness of intensive agricultural regions for recreation. The overall assessment of the potential of natural preconditions for recreation in \% of agricultural land is strongly influenced by the ecosystem of arable soils (Figure 7), which has higher share in total area of evaluated agroecosystems. According to Burkhard et al. [63], agricultural use of grassland has predominantly medium potential to provide recreational services (outdoor activities).

\section{Trade offs and Synergies between Agroecosystem Services}

Ecosystem services are non-lineary linked and changes in one service can impact the others in positive or negative way [58] [70] [71]. Spake et al. [71] define synergies when multiple services are enhanced simultaneously and trade-offs when the provision of one service is reduced due to increased use of another service. For identifying and mapping agroecosystem services associations with regards to known land use (arable land or grassland), climatic zone PCA analysis and Spearmans pairwise correlation analysis were used to evaluate the relationships between ecosystem services [58] [72].

The first axis (Figure 8) of principal component analysis biplot for agroecosystem services of arable land represents a spatial trade-offs between climatic zones and provisioning services, regulation of water regime, pollutants filtration and regulation of soil erosion. The second axis PC2 describese a synergy between climatic zones and clima regulation and their trade-offs with potential of natural conditions for recreation. The first two components accounted for $70 \%$ of the total variation in agroecosystem services. The trade-offs between climatic zones and provisioning services and regulation of water regime are more pronounced in the case of grassland.

Positively correlated agroecosystem services are assumed to be synergistic, while negative correlations infer trade-offs [58] [73] [74]. The relationship of individual services expressed through correlation coefficients is given in Table 3.

In the case of arable land trade-offs between the potential provisioning services and potential of climate regulation as well as potential of natural conditions for recreation was determined. The synergistic effect is between the provisioning agroecosystem service, regulation of water regime and soil cleaning (immobilization of inorganic pollutants). The similar relationships have been established for permanent grassland. However, in this land use management, there was no trade-offs between the potential provisioning services and potential of climate regulation as well as potential of natural conditions for recreation. The synergistic effect of regulation of water regime and soil state in its work Lescourret et al. [73]. Statistically significant synergistic effects are determined within each climatic area. Synergistic relationship between the potencial of erosion regulation and the potencial of water regime regulation as well as provisioning services has been established in all climatic regions. Only in moderate warm and very warm climatic region we have determined synergistic relationship between the potencial of provisioning services and the potencial of 
soil cleaning (immobilization of inorganic pollutants). In the moderate warm climate zone and warm climate zone, the potencial of provisioning services and the potencial of water regulation are also mutually beneficial.

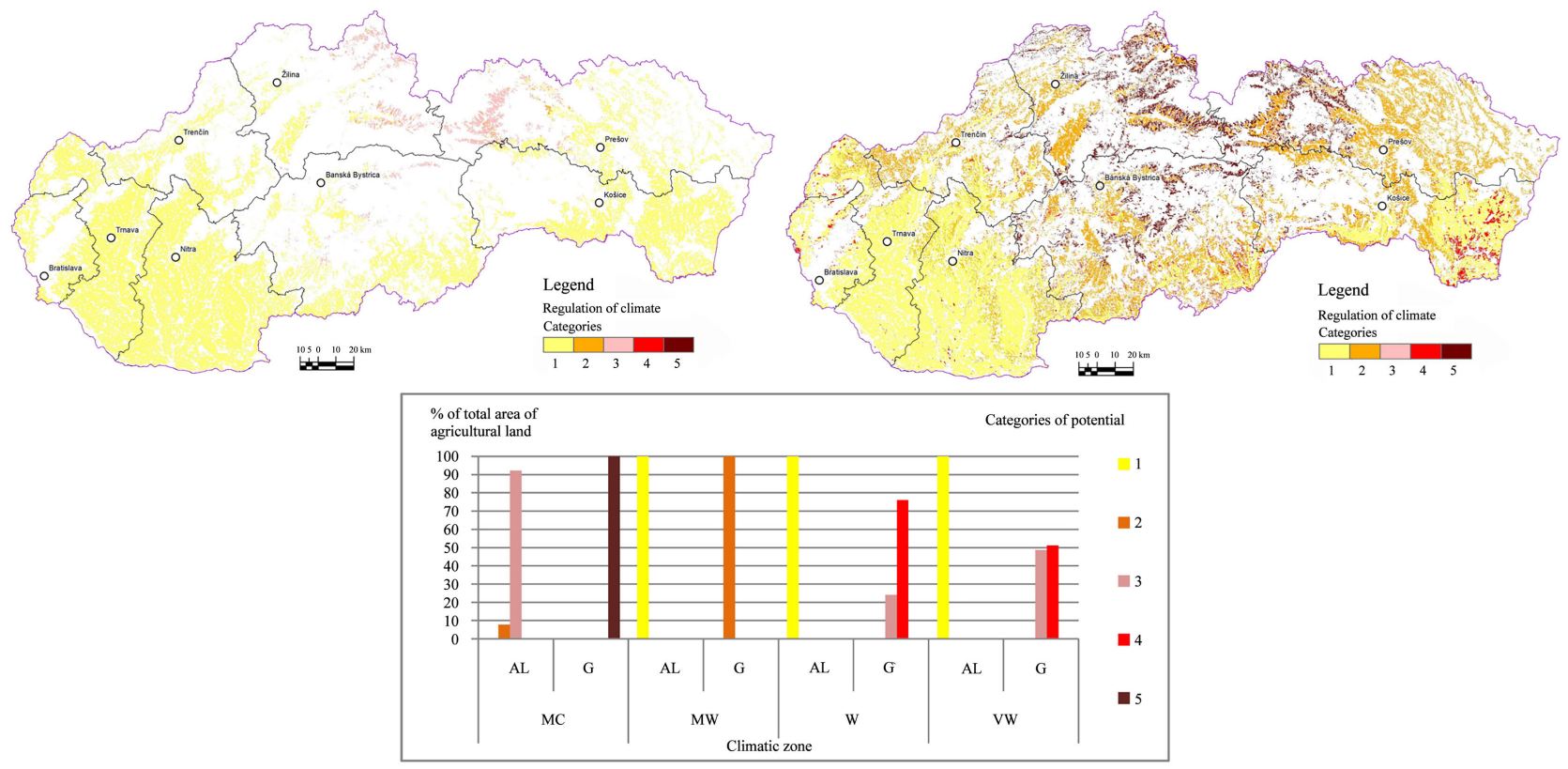

Figure 6. The climate regulation potential of agricultural land (arable land-AL-Figure to the left, grassland-G-Figure to the right), percentage of area for each category of potencial in four climatic regions. Explanations: the categoriesof potential: 1) very low potential, 2) low potential, 3) medium potential, 4) high potential, 5) very high potential.

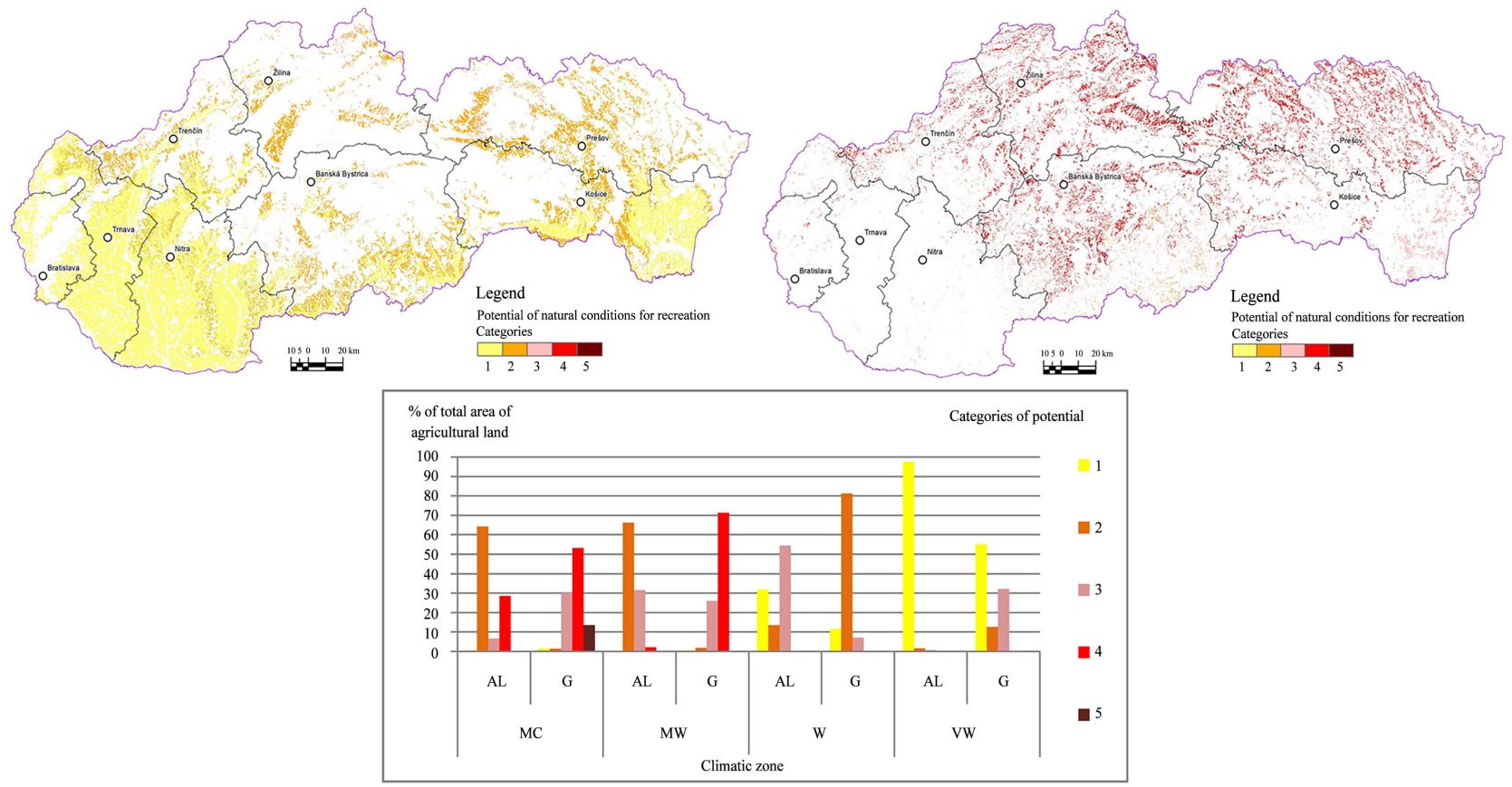

Figure 7. The potential for providing cultural ecosystem services of agricultural land, percentage of the area of each category of potencial in four climatic regions. Explanations: the categoriesof potential: 1) very low potential, 2) low potential, 3) medium potential, 4) high potential, 5) very high potential. 

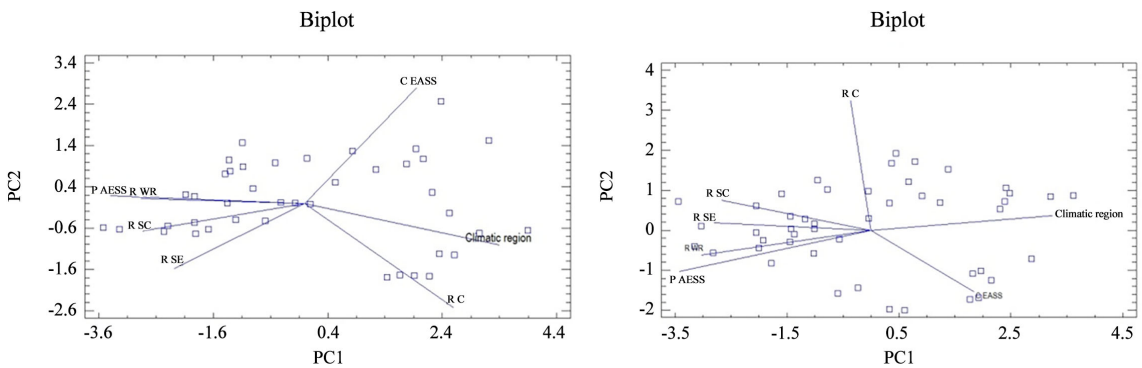

Figure 8. PCA analyse Biplot for arable land PCA analyse Biplot for grassland. Labels: PAESS-provisioning agroecosystem, RWR-Regulating water regime, RSC-regulating soil cleaning, RSE—regulating soil erosion, RC-regulating clima, CAESS—cultural agroecosystem services.

Table 3. Spearman correlations coefficients between agroecosystem services.

\begin{tabular}{|c|c|c|c|c|c|c|}
\hline \multicolumn{7}{|c|}{ Arable land } \\
\hline & \multirow{2}{*}{$\begin{array}{l}\text { Provisioning } \\
\text { services }\end{array}$} & \multicolumn{4}{|c|}{ Regulating services } & \multirow{2}{*}{$\begin{array}{l}\text { Cultural } \\
\text { services }\end{array}$} \\
\hline & & water & erosion & cleaning & clima & \\
\hline Provisioning services & - & & & & & \\
\hline water & $0.69^{* * *}$ & - & & & & \\
\hline \multirow{3}{*}{$\begin{array}{l}\text { Regulating } \\
\text { services }\end{array}$} & $0.52^{* * *}$ & $0.54^{* * *}$ & - & & & \\
\hline & $0.63^{* * *}$ & $0.36^{\star}$ & $0.33^{*}$ & - & & \\
\hline & $-0.62^{* * *}$ & $-0.47^{\star * *}$ & $-0.20 \mathrm{~ns}$ & $-0.33^{*}$ & - & \\
\hline Cultural services & $-0.41^{* *}$ & $-0.29^{\star}$ & $-0.31^{*}$ & $-0.46^{\star *}$ & $0.12 \mathrm{~ns}$ & - \\
\hline \multicolumn{7}{|c|}{ Permanent grassland } \\
\hline & \multirow{2}{*}{$\begin{array}{l}\text { Provisioning } \\
\text { services }\end{array}$} & \multicolumn{4}{|c|}{ Regulating services } & \multirow{2}{*}{$\begin{array}{l}\text { Cultural } \\
\text { services }\end{array}$} \\
\hline & & water & erosion & cleaning & clima & \\
\hline Provisioning services & - & & & & & \\
\hline \multirow{4}{*}{$\begin{array}{l}\text { Regulating } \\
\text { services }\end{array}$} & $0.75^{\star * *}$ & - & & & & \\
\hline & $0.62^{\star * *}$ & $0.51^{* * *}$ & - & & & \\
\hline & $0.49^{* * *}$ & 0.27 & $0.34^{*}$ & - & & \\
\hline & $-0.10 \mathrm{~ns}$ & $0.10 \mathrm{~ns}$ & 0.13 & 0.19 & - & \\
\hline Cultural services & -0.20 & -0.20 & -0.28 & -0.19 & -0.16 & - \\
\hline
\end{tabular}

Significance labels: ${ }^{* *} \mathrm{p}<0.001,{ }^{* *} \mathrm{p}<0.01,{ }^{*} \mathrm{p}<0.05$, ns: non significant.

\section{Conclusions}

This study applies a first assessment of agroecosystem services in the Slovak Republic and allows us to link the analysis of land use and differences of particular agroecosystem services in climatic regions. Evaluation of agroecosystem services linked to spatial visualization allows to optimize the management of agroecosystems, and thereby to promote synergies between ecosystem functioning and the social dynamics of the region. Provisioning, regulating and cultural ecosystem services of agricultural land are analyzed, modelled and evaluated in spatial grid 
scheme, which is replicable and could be applied by planners in case that they are proficient in geographical information systems. This proposed mapping system can also be used to assess agro ecosystem services in the regions and districts in the Slovak Republic that provide guidelines and limits for policy development on land management and land use changes at local and regional levels. Applying the agroecosystem service concept can help to show the effects of land use, climatic conditions as well as human interventions by qualitatively and quantitatively analyzing trade-offs between different services and by supporting the development of site-specific, more sustainable land use strategies. According to Burghard et al. 2013 and Krkoška, Lorencova et al. (2016), the mainstreaming of agroecosystem services into national policy and decision making needs to be futher supported by assessments based on local or national data and more accurate modelling approaches.

This study suggests that climate has the most significant impact on agroecosystem services. Warm, dry lowland region has a higher potential of provisioning services, regulation of water regime, filtration of pollutants and control of soil erosion in comparison to moderately warm and cold regions. In moderate cold region, more than $90 \%$ of the total arable land area has low potential for regulation water regime and cleaning potential (immobilization of risk elements). In moderate warm climatic region, there is a high share of categories of low and moderate potential of provisioning services and low and moderate potential of regulation of water regime. Majority of the total area of warm climatic region belongs to the categories of moderate to high potential of provisioning services and high potential of regulation of water regime. In this climatic zone categories of low potential of risk elements immobilization is present in more than $65 \%$ of the total arable land area. On the other hand, in very warm climatic zone, more than $89 \%$ of the total arable land area belongs to the category with very high cleaning potential (immobilization of risk elements). Potential of natural conditions for recreation is higher only in moderate cold and moderate warm climatic zones with higher proportion of grassland area agroecosystems and protected areas NATURA 2000.

Ecosystem services are non-lineary linked and changes in one service can impact the other in positive or negative way. High potential of provisioning service is linked to the high potential of regulation of water regime, pollutants filtration and soil erosion. The opposite trend has the potential provisioning services to potential of natural conditions for recreation. However, increasing of primary and secondary production of agroecosystems must be managed with regard to the sustainability of soil multifunctionality and also the sustainability of potential of agroecosystem to provide ecosystem services in their integrity. Agroecosystems management should always be oriented to the optimization of providing of the current needs within the sustainable use of agroecosystems.

\section{Acknowledgements}

The authors acknowledge the Slovak Research and Development Agency for the 
financial support via Project No. APVV-0098-12 "Analysis, modelling and evaluation of agroecosystem services" amd Project No. APVV-15-0160 "Elimination of degradation processes in soil by biodiversity restoring".

\section{Conflicts of Interest}

The authors declare no conflicts of interest regarding the publication of this paper.

\section{References}

[1] Nieto-Romero, M., Oteros-Rozas, E., Gonzáles, J.A. and Martin-López, B. (2013) Exploring the Knowledge Landscape of Ecosystem Services Assessments in Mediterranean Agroecosystems: Insights for Future Research. Environmental Science \& Policy, 37, 21-133.

[2] Burkhard, B., Kandziorai, M.S. and Müller, F. (2014) Ecosystem Service Potentials, Flows and Demands-Concepts for Spatial Localisation, Indication and Quantification. Official Journal of the International Association for Landscape Ecology (IALE-D), 34, 1-32.

http://www.landscapeonline.de/103097lo201434

https://doi.org/10.3097/LO.201434

[3] Frélichová, J., Vačkář, D., Pártl, A., Loučková, B., Harmáčková, Z. and Lorencová, E. (2014) Integrated Assessment of Ecosystem Services in the Czech Republic. Ecosystem Services, 8, 110-117. https://doi.org/10.1016/j.ecoser.2014.03.001

[4] Birghofer, K., Diehl, E., Andersson, J., Ekroos, J., Früh-Müller, A., Machnikowski, F., Mader, V.L., Nilsson, L., Sasaki, K., Rundlöf, M., Wolters, V. and Smith, H.G. (2015) Ecosystem Services-Current Challenges and Opportunities for Ecological Research. Frontiers in Ecology and Evolution, 2.

[5] Dominati, E., Patterson, M. and Mackay, A. (2010) A Framework for Classifying and Quantifying the Natural Capital and Ecosystem Services of Soils. Ecological Economics, 69, 1858-1868. https://doi.org/10.1016/j.ecolecon.2010.05.002

[6] Costanza, R. and Daly, H.E. (1992) Natural Capital and Sustainable Development. Conservation Biology, 6, 37-463. https://doi.org/10.1046/j.1523-1739.1992.610037.x

[7] Dominati, E.J. (2013) Natural Capital and Ecosystem Services of Soils. In: Dymond, J.R., Ed., Ecosystem Services in New Zealand-Conditions and Trends, Manaaki Whenua Press, Lincoln.

[8] Makovníková, J., Pálka, B., Širáň, M., Kanianska, R., Kizeková, M. and Jad’udová, J. (2017) Modeling and Evaluation Agroecosystem Services. (Modelovanie a Hodnotenie Agroekosystémových Služieb). Belianum Vydavatel'stvo Univerzity Mateja Bela, Banskej Bystrici.

[9] (2005) Ecosystems and Human Well-Being: Our Human Planet: Summary for Decision Makers. The Millennium Ecosystem Assessment Series, MEA (Millennium Ecosystem Assessment), Vol. 5, Island Press, Washington DC.

[10] Burkhard, B., Kroll, F., Nedkov, S. and Müller, F. (2012) Mapping Supply, Demand and Budgets of Ecosystem Services. Ecological Indicators, 21, 17-29. https://doi.org/10.1016/j.ecolind.2011.06.019

[11] Daniel, T.C., Muhar, A., Arnberger, A., Aznar, O. and von der Dunk, A. (2012) Contributions of Cultural Services to the Ecosystem Services Agenda. PNAS, 109, 8812-8819. https://doi.org/10.1073/pnas.1114773109 
[12] Forouzangohar, M., Crossman, N.D., Richard, J., MacEwan, R.J., DugalWallace, O. and Bennett, L.T. (2014) Ecosystem Services in Agricultural Landscapes: A Spatially Explicit Approach to Support Sustainable Soil Management. Scientific World Journal, 2014, Article ID: 483298.

[13] Dominati, E.J., Mackay, A., Lynch, B., Heath, N. and Millner, I. (2014) An Ecosystem Services Approach to the Quantification of Shallow Mass Movement Erosion and the Value of Soil Conservation Practices. Ecosystem Services, 9, 204-215. https://doi.org/10.1016/j.ecoser.2014.06.006

[14] Yaalon, D.H. and Arnold, R.W. (2000). Attitudes toward Soils and Their Societal rElevance: Then and Now. Soil Science, 65, 5-12. https://doi.org/10.1097/00010694-200001000-00003

[15] Vilček, J. and Koco, Š. (2018) Integrated Index of Agricultural Soil Quality in Slovakia. Journal of Maps, 14, 68-76. https://doi.org/10.1080/17445647.2018.1428233

[16] Coyle, C., Creamer, R.E., Schulte, R.P.O., O’Sullivan, L. and Jordan, P. (2016) A Functional Land Management Conceptual Framework under Soil Drainage and Land Use Scenarios. Environmental Science \& Policy, 56, 39-48.

[17] Haines-Young, R., Potschin, M. and Kienast, F. (2012) Indicators of Ecosystem Service Potential at European Scales: Mapping Marginal Changes and Trade-Offs. Ecological Indicartos, 21, 39-53. https://doi.org/10.1016/j.ecolind.2011.09.004

[18] Greiner, L., Keller, A., Gret-Regamey, A. and Papritz, A. (2017) Soil Function Assessment: Review of Methods for Quantifying the Contributions of Soils to Ecosystem Services. Land Use Policy, 69, 224-237. https://doi.org/10.1016/j.landusepol.2017.06.025

[19] Juráni, B. (2005) Protection, Land Use and Human Impact (Ochrana, využívanie pôdy a vplyv človeka). In: Sobocká, J., Ed., Proseedings of Soil Science Conference, Societas Pedologica Slovaca and Soil Science and Conservation Research Institute, Bratislava, 178-180. (In Slovak)

[20] Bujnovský, R., Vilček, J., Blaas, G., Skalský, R., Barančíková, G., Makovníková, J., Balkovič, J. and Pálka, B. (2011) Assessment of Capacities of Soil and Effects from Its Use (Hodnotenie kapacít pôdy a efektov z jej využívania). Soil Science and Conservation Research Institute, Bratislava, 70 p. (In Slovak)

[21] Makovníková, J., Barančíková, G. and Pálka, B. (2007) Approach to the Assessment of Transport Risk of Inorganic Pollutants Based on the Immobilisation Capability of Soil. Plant, Soil and Environment, 53, 365-373. https://doi.org/10.17221/2215-PSE

[22] Barančíková, G., Koco,Š, Makovníková, J. and Torma, S. (2010) Filter and Transport Functions of Soil. Soil Science and Conservation Research Institute, Bratislava, 33 p. (In Slovak)

[23] MEA (Millennium Ecosystem Assessment) (2007) A Toolkit for Understanding and Action. Protecting Natures Services. Protecting Ourselves. Island Press, Washington DC, $28 \mathrm{~s}$.

[24] TEEB (2010) The Ecnomics of Ecosystems and Biodiversity: Ecological and Economic Foundationd. Earthscan, London and Washington DC.

[25] Burkhard, B., Crossman, N., Nedkov, S., Petz, K. and Alkemade, R. (2013) Mapping and Modelling Ecosystem Services for Science, Policy and Practice. Ecosystem Services, 4, 1-3. https://doi.org/10.1016/j.ecoser.2013.04.005

[26] Costanza, R. (2017) Twenty Years of Ecosystem Services: How Far Have We Come and How Far Do We Still Need to Go? Ecosystem Services, 28, 1-16. 
https://doi.org/10.1016/j.ecoser.2017.09.008

[27] Burkhard, B. and Maes, J. (2017) Mapping Ecosystem Services. Advanced Books.

[28] Scolozzi, R., Morri, E. and Santolini, R. (2012) Delphi-Based Change Assessment in Ecosystem Service Values to Support Strategic Spatial Planning in Italian Landscapes. Ecological Indicators, 21, 134-144. https://doi.org/10.1016/j.ecolind.2011.07.019

[29] Makovníková, J., Kobza, J., Pálka, B., Mališ, J., Kanianska, R. and Kizeková, M. (2016) An Approach to Mapping the Potential of Cultural Agroecosystem Services. Soil and Water Research, 11, 44-52. https://doi.org/10.17221/109/2015-SWR

[30] Crossman, N.D., Burkhard, B., Nedkov, S., Willemen, L., Petz, K., Palomo, I., Drakou, E.G., Martín-Lopez, B., McPhearson, T., Boyanova, K., Alkemade, R., Egoh, B., Dunbar, M. and Maes, J. (2013) A Blueprint for Mapping and Modelling Ecosystem Services. Ecosystem Services, 4, 4-14. https://doi.org/10.1016/j.ecoser.2013.02.001

[31] Naidoo, R., Balmford, A., Costanza, R., Fisher, B., Green, R.E., Lehner, B., Malcolm, T.H. and Ricketts, T.H. (2008) Global Mapping of Ecosystem Services and Conservation Priorities. Proceedings of the National Academy of Sciences of the USA, 105, 9495-9500. https://doi.org/10.1073/pnas.0707823105

[32] Schulp, C.J.E., Lautenbach, S. and Verburg, P.H. (2014) Quantifying and Mapping Ecosystem Services: Demand and Supply of Pollination in the European Union. Ecological Indicators, 36, 131-141. https://doi.org/10.1016/j.ecolind.2013.07.014

[33] Bateman, I.J., Mace, G.M., Fezzi, C., Atkinson, G. and Turner, K. (2011) Economic Analysis for Ecosystem Service Assessments. Environmental and Resource Economics, 48, 177-218. https://doi.org/10.1007/s10640-010-9418-x

[34] Hönigová, I., Vackár, D., Lorencová, E., Melichar, J., Götzl, M., Sonderegger, G., Oušková, V., Hošek, M. and Chobot, K. (2012) Survey on Grassland Ecosystem Services, Report to the European Topic Centre on Biological Diversity. Nature Conservation Agency of the Czech Republic, Prague, 78.

[35] Frélichová, J. and Fanta, J. (2015) Ecosystem Service Availability in View of Long-Term Land-Use Changes: A Regional Case Study in the Czech Republic. Ecosystem Health and Sustainabilty, 1, 1-15. https://doi.org/10.1890/EHS15-0024.1

[36] Olosutean, H. (2017) Methods for Modeling Ecosystem Services: A Review. Management of Sustainable Development, 7, 5-12.

[37] Maes, J., Braat, L., Jax, K., Hutchins, M., et al. (2011) A Spatial Assessment of Ecosystem Services in Europe: Methods, Case Studies and Policy Analysis-Phase 1. PEER Report No. 3, Partnership for European Environmental Research, Ispra.

[38] Hamnett, R.G. (2006) Country Pasture/Forage Resources Profile-Slovakia. http://www.fao.org/ag/agp/agpc/doc/Counprof/slovak/slovakia.htm

[39] NAFC-SSCRI (2015) Distribution of Agricultural Land in Agro-Climatic Regions of Slovakia. http://www.podnemapy.sk/portal/reg_pod_infoservis/klima/klima.aspx

[40] Džatko, M., Mašát, K. and Cambel, B. (1989) Agroclimatic Regions SR-VCPÚ-ÚPVR, Bratislava.

[41] Čurlík, J. (2011) Potential Toxic Trace Elements and Their Distribution in the Soils of Slovakia. Faculty of Natural Sciences, Comenius University, Bratislava. (In Slovak)

[42] Kobza, J., Barančíková, G., Dodok, R., Hrivňáková, K., Makovníková, J., Pálka, B., Pavlenda, P., Schlosserová, J., Styk, J. and Širáň, M. (2014) Soil Monitoring of the Slovak Republic (Monitoring pôd SR). National Agriculture and Food Centre-Soil 
Science and Conservation Research Institute, Bratislava, 252. (In Slovak)

[43] Van Camp, B., Bujarrabal, A.R., Gentile, R.J.A., Jones, L., Montanarella, L., Olazabal, O. and Selvaradjou, S.K. (2004) Reports of the Technical Working Groups Established under the Thematic Strategy for Soil Protection. EUR 21319 EN/5, 872. Office for Official Publications of the European Communities, Luxembourg.

[44] Alam, M., Dupra, J. and Messier, C.H. (2016) A Framework towards a Composite Indicator for Urban Ecosystem Services. Ecological Indicators, 60, 38-44. https://doi.org/10.1016/j.ecolind.2015.05.035

[45] Seják, J., Dejmal, I., Petříček, V., Cudlín, P., Míchal, I., Černý, K., Kučera, T., et al. (2003) Assessment and Valuation of Biotopes of the Czech Republic. Praha, 428. (In Czech)

[46] Džatko, M. (2002) Evaluation of Production Potential of Agricultural Land and Soil-Ecological Regions of Slovakia. Soil Science and Conservation Research Institute, Bratislava, 87. (In Slovak)

[47] Bujnovský, R., Balkovič, J., Barančíková, G., Makovníková, J. and Vilček, J. (2009) Assessment and Valuation of Ecological Functions of Agricultural Land in Slovakia. Soil Science and Conservation Research Institute, Bratislava, 72. (In Slovak)

[48] Wischmeier, W.H. and Smith, D.D. (1978) Predicting Rainfall Erosion Losses: Guide to Conservation Planning. Agricultural Handbook No. 537, USDA, 58 p.

[49] Majtaníková, J. (2011) Vyhodnotenie eróznej ohrozenosti vybraného pôdneho celku na území povodia Hostovského potoka. In: Krajinné inžinierstvo-súčasný stav a výhlad do budúcnosti, Slovenská polnohospodárska univerzita, Nitra. http://www.slpk.sk/eldo/2011/zborniky/07-11/majtanikova.pdf

[50] Barančíková, G., Gutteková, M., Halas, J., Koco, Š., Makovníková, J., Nováková, M., Skalský, R., Tarasovičová, Z. and Vilček, J. (2011) Soil Organic Carbon in the Agricultural Landscape-Modeling of Changes in Space and Time. Soil Science and Conservation Research Institute, Bratislava, 85 p. (In Slovak)

[51] Sherrouse, B.C., Clement, J.M. and Semmens, D.J. (2011) A GIS Application for Assessing, Mapping, and Quantifying the Social Values of Ecosystem Services. Applied Geography, 31, 748-760. https://doi.org/10.1016/j.apgeog.2010.08.002

[52] Krkoška Lorencová, E., Harmáčková, Z.V., Landová, L., Pártl, A. and Vačkář, D. (2016) Assessing Impact of Land Use and Climate Change on Regulating Ecosystem Services in the Czech Republic. Ecosystem Health and Sustainability, 2, e01210. https://doi.org/10.1002/ehs2.1210

[53] Kanianska, R., Jad’udová, J., Makovníková, J. and Kizeková, M. (2016) Assessment of Relationships between Earthworms and Soil Abiotic and Biotic Factors as a Tool in Sustainable Agricultural. Sustainability, 8, 906.

[54] EEA (2013) Technical Report No. 11/2013. The European Grassland Butterfly Indicator: 1990-2011. Publications Office of the European Union, Luxembourg, 36 p.

[55] Montoya, J.M. and Raffaelli, D. (2010) Climate Change, Biotic Interactions and Ecosystem Services. Philosophical Transactions of the Royal Society B, 365, 2013-2018. https://doi.org/10.1098/rstb.2010.0114

[56] Birkhofer, K. and Wolters, V. (2012) The Global Relationship between Climate, Net Primary Production and the Diet of Spiders. Global Ecology and Biogeography, 21, 100-108. https://doi.org/10.1111/j.1466-8238.2011.00654.x

[57] Diehl, E., Sereda, E., Wolters, V. and Birkhofer, K. (2013) Effects of Predator Specialization, Host Plant and Climate on Biological Control of Aphids by Natural 
Enemies: A Meta-Analysis. Journal of Applied Ecology, 50, 262-270. https://doi.org/10.1111/1365-2664.12032

[58] Spake, R., et al. (2017) Unpacking Ecosystem Service Bundles: Towards Predictive Mapping of Synergies and Trade-Offs between Ecosystem Services. Global Environmental Change, 47, 37-50. https://doi.org/10.1016/j.gloenvcha.2017.08.004

[59] Kvitkovič, J. (1964) Concerning the Basic Geomorphological Problems of the East-Slovakian Lowland. Geografický Časopis, 20, 143-159. (In Slovak)

[60] Yong, R.N., Mohamed, A.M.O. and Warkentin, B.P. (1992) Principles of Contaminant Transport in Soils. Elsevier, London.

[61] Barančíková, G. and Makovníková, J. (2003) The Influence of Soil Humic Acid Quality on Sorption and Mobility of Heavy Metals. Plant, Soil and Environment, 49, 565-571. https://doi.org/10.17221/4195-PSE

[62] Makovníková, J. and Barancíková, G. (2009) Assessment of Transport Risk of Cadmium and Lead on the Basis of Immobilisation Capability of Soil. Soil and Water Research, 1, 10-16.

[63] Burkhard, B., Kroll, F., Müller, F. and Windhorst, W. (2009) Landscapes' Capacities to Provide Ecosystem Services-A Concept for Land-Cover Based Assessments. Landscape Online, 15, 1-22.

[64] Širáň, M., Makovníková, J. and Barančíková, G. (2013) Monitoring of Soil Bulk Demsity-Basis for Determination of Organic Matter Stock in Soil. Proseedings of Soil Science and Conservation Research Institute, Bratislava, 166-173. (In Slovak)

[65] Campbell, C.A. and Souster, W. (1982) Loss of Organic Matter and Potentially Mineralizable Nitrogen from Saskatchewan Soils Due to Cropping. Canadian Journal of Soil Science, 62, 651-656. https://doi.org/10.4141/cjss82-071

[66] Schnitzer, M., Mcarthur, D.F.E., Schulten, H.R., Kozak, L.M. and Huang, P.M. (2006) Long-Term Cultivation Effects on the Quality and Quantity of Organic Mater in Selected Canadian Prairie Soils. Geoderma, 130, 141-156. https://doi.org/10.1016/j.geoderma.2005.01.021

[67] Bielek, P., Šurina, B., Ilavská, B. and Vilček, J. (1998) Our Soils (Agricultural) (Naše pôdy (polnohospodárske)). Soil Science and Conservation Research Institute, Bratislava, 80. (In Slovak)

[68] Conant, R.T., Ryan, M.G., Ågren, G.I., Birge, H.E., Davidson, E.A., Eliasson, P.E., Evans, S.E., Frey, S.D., Giardina, C.P., Hopkins, F.M., Hyvönen, R., Kirschbaum, M.U.F., Lavallee, J.M., Leifeld, J., Parton, W.J., Steinweg, J.M., Wallenstein, M.D., Wetterstedt, J.A.M. and Bradford, M.A. (2011) Temperature and Soil Organic Matter Decomposition Rates-Synthesis of Current Knowledge and a Way Forward. Global Change Biology, 17, 3392-3404. https://doi.org/10.1111/j.1365-2486.2011.02496.x

[69] Martens, S.N., Breshears, D.D. and Meyer, C.W. (2000) Spatial Distributions of Understory Light along the Grassland/Forest Continuum: Effects of Cover, Height, and Spatial Pattern of Tree Canopies. Ecological Modeling, 126, 79-93. https://doi.org/10.1016/S0304-3800(99)00188-X

[70] Felipe-Lucia, M.R., Comin, F.A. and Bennett, E.M. (2014) Interactions among Ecosystem Services across Land Uses in a Floodplain Agroecosystem. Ecology and Society, 19, Art. 20. https://doi.org/10.5751/ES-06249-190120

[71] Mahbubul, A., Duprasb, J. and Messier, C.H. (2016) A Framework towards a Composite Indicator for Urban Ecosystem Services. Ecological Indicators, 60, 38-44. https://doi.org/10.1016/j.ecolind.2015.05.035 
[72] Mouchet, M.A., Paracchini, M.L., Schulp, C.J.E., Stürck, J., Verkerk, P.J., Verburg, P.H. and Lavorel, S. (2017) Bundles of Ecosystem (Dis-)Services and Multifunctionality across European Landscapes. Ecological Indicators, 7, 23-28. https://doi.org/10.1016/j.ecolind.2016.09.026

[73] Lescourret, F., Magda, D., Richard, G., Blondon, A.F.A., Bardy, M., Baudry, J., Doussan, I., Dumont, B., Lefèvre, F., Litrico, I., Clouaire, R.M., Montuelle, B., Pellerin, S., Plantegenest, M., Tancoigne, E., Thomas, A., Guyomard, H. and Soussana, L.F. (2015) A Social-Ecological Approach to Managing Multiple Agro-Ecosystem Services. Environmental Sustainability, 14, 68-75.

[74] Tomscha, S.A. and Gergel, S.E. (2016) Ecosystem Service Trade-Offs and Synergies Misunderstood 838 without Landscape History. Ecology and Society, 21, 43.

https://doi.org/10.5751/ES-08345-210143 